\title{
Kepuasan Hidup Pekerja Perempuan: Sebuah Tinjauan Konseptual
}

\author{
Muthia Pramesti ${ }^{1}$, Isbandi Rukminto Adi ${ }^{2}$, Riani Rachmawati ${ }^{3}$ \\ ${ }^{1,3}$ Departemen Manjemen, Fakultas Ekonomi dan Bisnis, Universitas Indonesia, \\ muthia.pramesti@ui.ac.id, riani.rachmawati@gmail.com \\ ${ }^{2}$ Departemen Kesejahteraan Sosial, Fakultas Ilmu Sosial dan Politik, Universitas Indonesia, \\ adi1126@yahoo.com
}

\section{Received: 21/09/2021. \\ Reviewed: 26/11/2021. \\ Published: 31/12/2021}

Copyright $\odot 2021$ by the author (et al) and Jurnal Sosial Humaniora (JSH)

*This work is licensed under the Creative Commons Attribution International License (CC BY 4.0). http://creativecommons.org/licenses/by/4.0/ (c) (i) Open Access

\begin{abstract}
Subject Area: Law \& Socio-economics
Abstract

This paper aims to conduct a conceptual study of factors that drive life satisfaction in the work domain for female workers. They experience several problems related to human resource policies related to their personal and work life. The dual role as breadth winner and housewife often take place. Life satisfaction is interesting to be discussed due to the well-being challenges for female workers. The framework is built by "Top-Down" and "Bottom-Up" theory. The author conducted an electronic-based data search from 58 articles during the 2019-2021 period. Several factors affect job satisfaction, such as need fulfilment, self-development and work pressure. In the discussion section, it will explain the factors driving workers' life satisfaction to life, especially for female workers.
\end{abstract}

Keywords: life satisfaction; subjective well being; work doman; female worker

\section{Pendahuluan}

Konsep Life Satisfaction (Kepuasan Hidup) dan Happiness (kebahagiaan) menjadi bagian dari terminologi Subjective Well-Being ( $S W B$ ), yang membahas mengenai pengukuran, faktor penyebab dan teori mengenai kesejahteraan subjektif. Kesejahteraan subjektif adalah persepsi kualitas hidup seseorang dan indeks komprehensif yang penting untuk mengukur evaluasi afektif dan kognitif kehidupan seseorang, di mana terdapat dua pendekatan yaitu top down dan bottom up (Diener 1984). Kepuasan hidup adalah penilaian umum mengenai kualitas hidup seseorang, atas dasar kriteria yang dipilihnya, sehingga pengukuran kepuasan hidup yang relevan untuk diterapkan adalah aspek subjektivitas individu, dibandingkan obyektifitas (D.C.Shin;D.M. Johnson 1978). Hal ini dikarenakan kepuasan hidup melibatkan aspek afeksi positif, dibanding kognitif. (Ed, Diener. Robert A, Emmons. Randy J 1985) melakukan konstruksi atas pengukuran kepuasan hidup dengan menggunakan Satisfaction with Life Scale (SWLS). Kebahagiaan dapat diidentifikasi melalui pekerjaan yang dijalankannya, kesesuaian peran individu terhadap pekerjaan (work-role related), nilai dari sebuah pekerjaan dan skala kebermaknaan psikologis (psychological meaningfulness) dan keterlibatan kerja (work engagement) (Llewellyn E. vanZyl, Elmari Deacon 2010). 
Gender digunakan untuk menginterpretasikan perbedaan perempuan dan laki-laki, dalam hal peran, status, tanggung jawab, dan konstruksi berdasarkan nilai-nilai dan budaya masyarakat setempat. Perbedaan perempuan dan laki-laki dideskripsikan melalui karakteristik yang terlihat seperti organ fisik dan hormon, sifat biologis dan psikologis lainnya (Hanlon 2013). Di Asia, perempuan dan laki-laki terlihat berbeda dari pekerjaannya, fungsi dalam rumah tangga, status di masyarakat juga gaya hidup. Perempuan biasanya tidak diposisikan untuk mengambil peran sebagai pencari nafkah, namun demikian fenomena perempuan bekerja semakin meningkat, dikarenakan tuntutan ekonomi dan tingkat pendidikan perempuan. Kampanye mengenai kesetaraan gender semakin sering digalakkan dalam area pekerjaan agar perempuan memiliki kesepadanan pendapatan, status, kesempatan untuk promosi dan banyak hal lain. Saat ini, kebijakan ketenagakerjaan sudah mulai memperlihatkan upaya kesamaan arah pada pekerja perempuan dan laki-laki untuk menuju tujuan yang sama yaitu kepuasan hidupnya (Levesque 2011). Studi Navarro \& Salverda (2019) menyimpulkan bahwa perbedaan gender memberikan pengaruh pada kepuasan pekerjaan dan kehidupan.

Beberapa penelitian yang dilakukan di beberapa negara, menunjukkan bahwa kelompok perempuan memiliki kepuasan hidup yang lebih tinggi dibandingkan kelompok laki-laki. Namun, perempuan kerap mengalami keadaan emosi yang fluktuatif, sehingga berpotensi menimbulkan depresi dan kekhawatiran (Misheva, 2016). Kelompok perempuan memiliki tiga poin lebih tinggi dibandingkan laki-laki dalam kepuasan hidupnya, yang disebabkan oleh bias individu yang diterima oleh pekerja di mana mereka menganggap kepuasan hidup bersumber dari kesuksesan karir dan kemampuan untuk mencapai kebutuhan. Area pekerjan yang dijalankan oleh perempuan dapat meliputi area pekerjaan formal dan informal. Pekerja perempuan formal bekerja dengan komitmen waktu dan kompensasi yang telah disepakati dengan pemberi kerja, seperti: perempuan pekerja di perusahaan/sekolah/organisasi atau buruh pabrik. Sementara pekerja informal bekerja di luar organisasi formal, seperti pekerja mandiri (self employed), pekerja harian lepas tanpa kontrak kerja formal atas dasar waktu dan kompensasi serta produktivitasnya. Saat ini bidang pekerjaan yang dijalankan oleh pekerja perempuan sangat beragam, meliputi manufaktur dan jasa di bidang pendidikan, perbankan, pengolahan, hukum, pertambangan, otomotif, komersial dan lainnya (Klaveren et al. 2010).

\section{Kajian Pustaka}

Kajian teoritis mengenai kepuasan hidup dapat diklasifikasikan menjadi dua pendekatan, yaitu pendekatan Top-Down dan pendekatan Bottom-Up.

\section{Pendekatan Top-Down}

Pendekatan top-down menjelaskan bahwa kepuasan hidup adalah fungsi dari sifat manusia yang berlangsung stabil, karena individu memiliki kecenderungan mencapai kepuasan hidupnya. Dengan menggunakan uji kepribadian Big Five Model, terdapat 137 kepribadian yang menunjukkan hubungan antara kepuasan hidup dan kesejahteraan subjektif. Namun demikian, sifat manusia (traits) akan dipengaruhi oleh kejadian dalam hidup (life event) serta kestabilan emosi (Deneve and Copper 1998). Penelitian Oishi et al. (1999) menjelaskan bahwa nilai dominan akan menentukan faktor pendorong kepuasan hidup. Pendekatan top-down tidak menegasikan pengaruh faktor situasional pada life events. Yang mempengaruhi kebahagiaan dan kepuasan hidup adalah traits, personality dan faktor lain, seperti kejadian yang dialami seorang individu. 


\section{Pendekatan Bottom-Up}

Pendekatan Bottom-Up memperlakukan kepuasan hidup sebagai fungsi dari peristiwa kehidupan yang berlangsung atau domain kehidupan (Pavot dan Diener, 2008). Sehingga kesejahteraan subjektif selalu mengalami perubahan dari masa ke masa, seiring dengan perubahan nilai dan perkembangan kepribadian. Model kepuasan hidup menyimpulkan bahwa terdapat hubungan yang kuat antara kepuasan hidup dan peristiwa kehidupan yang dapat distimulasi atas perubahan pada kondisi sosial yang terjadi (Oishi et al., 1999). Kehidupan memiliki keterkaitan dengan domain kehidupan lain, seperti pekerjaan, keluarga, kesehatan, kesenangan dan lainnya. Proses yang kompleks akan berlangsung pada domain kehidupan seseorang. Prioritas individu mengenai kepuasan hidupnya searah dengan nilai yang dianut seseorang mengenai hal yang dianggap nya penting dalam kepuasan hidupnya (Oishi et al., 1999). Wu (2009) dalam studinya menyimpulkan bahwa terdapat individu yang menilai pencapaian lebih penting, sementara individu lain menilai hubungan dengan orang lain lebih penting. Tingkatan work-family satisfaction akan memiliki nilai yang berbeda dalam kepuasan hidup individu. Ketidakpuasan atas sebuah domain akan mendorong individu melakukan penilaian ulang mengenai pentingnya sebuah domain. Pekerjaan yang dijalankan oleh perempuan pekerja yang bersifat formal dan informal di berbagai macam bidang dapat menjadi bagian dari domain kehidupan yang mempengaruhi kepuasan hidup.

\section{Kerangka Konsepual}

\section{Kepuasan hidup dan Domain Pekerjaan}

Kepuasan hidup diduga memiliki hubungan dan pekerjaan karena menjadi bagian dominan dalam kehidupan seorang pekerja. Beberapa faktor pendorong kepuasan hidup dari pekerja adalah :

\section{Bekerja sebagai Sumber Kepuasan Kebutuhan (Need Satisfaction)}

\section{Kebutuhan Finansial}

Pekerjaan dapat menjadi sumber kepuasan atas dasar pemenuhan kebutuhan keuangan. Kajian ini konsisten dengan pandangan bahwa pengangguran memiliki dampak negatif pada kepuasan hidup dan kesejahteraan (Ervasti and Venetoklis 2010). Studi (Winefield et al. 1991) menyatakan hal senada bahwa kelompok yang tidak mencapai kepuasan hidup adalah kelompok pengangguran, sementara kelompok yang bekerja dan mahasiswa memiliki kepuasan yang lebih tinggi disebabkan aspek harga diri, tingkat depresi dan suasana hati. Luhmann \& Eid (2009) menemukan bahwa individu belajar beradaptasi pada peristiwa kehidupan yang negatif yang dialaminya secara berulang kali. Namun demikian, kondisi menganggur yang dialami secara berulang dapat memiliki efek majemuk pada kepuasan hidup. Kondisi ekonomi dapat memperburuk pengaruh pengangguran. Hal ini dikarenakan adanya tekanan ekonomi dari kondisi lokal yang buruk, sehingga dapat meningkatkan tekanan ekonomi (Jørgen Goul Andersen 2002).

2. Kebutuhan Interpersonal

Manusia memiliki kebutuhan yang tinggi untuk menjalin hubungan jangka panjang dan saling mendukung satu sama lain. (Wanous, Reichers, and Hudy 1997) menjelaskan bahwa terdapat korelasi positif antara dukungan sosial di tempat kerja (rekan kerja, manajer, dan dukungan organisasi) dan kepuasan hidup. 
Penelitian yang melibatkan 400 orang dewasa Australia, menunjukkan bahwa kesepian (loneliness) menurunkan kepuasan hidup. Hubungan sosial terbangun atas ikatan pertemanan dekat dan pernikahan (Myers and Diener 1995). Lingkungan kerja yang kondusif berkorelasi dengan kepuasan hidup, dengan peran rekan kerja yang sedikit lebih penting daripada supervisor. Fusilier et al. (1986) menemukan bahwa terdapat hubungan positif antara kepuasan hidup dan hubungan dengan rekan kerja, tetapi tidak berlaku dengan atasan. Simon et al. (2010) menunjukkan bahwa individu dengan tingkat agreeableness yang tinggi cenderung memiliki hubungan dengan rekan kerja dan kepuasan hidup yang lebih kuat dibandingkan dengan kelompok dengan tingkat agreeableness yang rendah.

\section{Kekuasaan (Power) dan Status}

Fritz et al. (2010) menunjukkan bahwa posisi individu pada organisasi, prestise pekerjaan dan manuver untuk bergerak ke posisi di atasnya berhubungan dengan kepuasan hidup, yang didorong oleh kekuasaan (power) dan status. Power dan status pekerjaan berhubungan dengan kepuasan hidup pada angka 0,38 (Judge et al. 1998). Burke et al. (2009) menyebutkan bahwa terdapat korelasi positif antara posisi manajer dan kepuasan hidupnya. Todd et al (2009) memperoleh kesimpulan bahwa keterampilan untuk berpolitik memiliki hubungan dengan dimensi karir (promosi, kompensasi, kepuasan karir, kepuasan hidup).

\section{Pekerjaan sebagai Aktivitas untuk Berkembang}

1. Tantangan

Davis \& Csikszentmihalyi (1977) berpendapat bahwa kepuasan seseorang adalah fungsi dari tantangan yang optimal yang diberikan kepada pekerja. Myers \& Diener (1995) menunjukkan pentingnya tantangan untuk mencapai kepuasan hidup. Judge et al. (1998) menggunakan variasi keterampilan (skill variety), signifikansi tugas (task significance), dan umpan balik (feedback), dengan korelasi dengan kepuasan hidup sebesar 0.54 untuk dokter dan 0.30 untuk lulusan perguruan tinggi. Staines et al (2015) menggunakan ukuran tantangan pekerjaan yang terdiri dari item yang berkaitan dengan tantangan, otonomi, dan variasi keterampilan, lalu menemukan korelasi yang positif. Sehingga dapat disimpulkan bahwa karakteristik pekerjaan secara intrinsik lebih memotivasi dan menghasilkan pengalaman kerja yang bermakna secara keseluruhan.

\section{Pertumbuhan}

Pekerjaan juga memberikan kesempatan untuk berkembang, sehingga memberikan tahapan kemajuan untuk mencapai tujuan hidupnya. Pekerjaan searah dengan pencapaian tujuan hidup yang dimiliki oleh pekerja (Greguras dan Diefendorff, 2010). Kesempatan belajar memberikan hasil korelasi yang moderat dengan kepuasan hidup. Dengan kata lain, pekerja akan mencapai kepuasan yang lebih tinggi dengan adanya pengalaman belajar, pelatihan dan pengembangan pada pekerjaannya, dibandingkan jika hanya diberikan kesempatan.

3. Kebermaknaan.

Melakukan pekerjaan yang selaras dengan keterampilan, minat dan nilai seseorang dapat meningkatkan peluang menemukan kebermaknaan di lingkungan tempat bekerja dan mempengaruhi kepuasan hidup. Kesesuaian antara pekerjaan dan personal akan relevan untuk kepuasan hidup. 
Kebermaknaan dapat dicapai melalui otonomi (autonomy) di tempat kerja, dimana karyawan dapat dengan bebas memilih dan melakukan kegiatan kerjanya, sehingga menganggap pekerjaan sebagai sesuatu yang bermakna (Day and Jreige 2002). Rau (2006) menjelaskan 185 karyawan Jerman yang terlibat dengan pengambilan keputusan menghasilkan hubungan yang kuat atas kepuasan hidup. De Cuyper \& De Witte (2006) menunjukkan bahwa otonomi memiliki korelasi sebesar 0,47 menjadi faktor pendorong terhadap kepuasan hidup.

\section{Tekanan Konteks Pekerjaan (Work-Context Stressor)}

Kepuasan atas kehidupan dapat dipicu oleh peristiwa yang bersifat positif dan negatif. Kondisi pekerjaan akan menjadi sumber ketegangan dan kepuasan. Oleh karena itu, stressor (pemicu ketegangan) dapat menjadi anteseden yang memprediksikan kepuasan hidup. Beberapa studi mempertimbangkan keseimbangan konflik pekerjaan dan kehidupan, stressor dari pekerjaan itu sendiri dan peranan stressor.

1. Konflik Pekerjaan dan Kehidupan

Konflik pekerjaan dan kehidupan adalah salah satu sumber tekanan pada pekerjaan. Berdasarkan Wilensky (1960), domain kehidupan dan pekerjaan memiliki tiga tipe hubungan satu sama lain, yaitu kompensasi, segmentasi dan spill over. Hipotesis kompensasi menjelaskan bahwa individu mencari reward dari satu domain yang akan mengkompensasi domain lainnya yang tidak memuaskan. Sementara hipotesis segmentasi menyebutkan bahwa domain kehidupan tidak terhubung satu sama lain. Sementara, Sementara, hipotesis spillover menyatakan bahwa apa yang terjadi pada satu domain akan saling bertumpang-tindih domain kehidupan yang lainnya.

Judge dan Watanabe (1994) menemukan bahwa hipotesis spillover berlangsung sebanyak 68\% dari populasi, terdapat pengaruh negatif dari konflik pekerjaan-kesenangan (Robert, W. Rice Michael R. Frone. B, 1992), konflik pekerjaan-rumah tangga atau konflik pekerjaan-non pekerjaan (Babin \& Boles, 1998). Konflik pekerjaan dan keluarga memiliki pengaruh yang lebih besar pada kepuasan hidup (Allen et al., 2000). Stressor dari Pekerjaan

\section{Tekanan Pekerjaan}

Pekerjaan dapat menjadi salah satu sumber tekanan. Frekuensi dan intensitas dari pekerjaan seharihari akan berpengaruh pada kepuasan hidup (Hart, 1999). Kerepotan menyelesaikan tugas harian dan hubungan dengan supervisor berpengaruh pada kepuasan hidup (Maybery et al., 2007). Studi yang dilakukan oleh Gadermann \& Zumbo (2007) menemukan hasil yang serupa dimana aktivitas kerja harian yang menjengkelkan, kurangnya privasi, dimanfaatkan orang lain, interupsi yang tidak diinginkan akan menimbulkan kerepotan kecil, namun akan memberikan pengaruh pada kepuasan hidup.

\section{Stressor dari Peran (Role Stressor)}

Dorongan untuk mencapai performa yang baik yang dipicu oleh tuntutan pekerjaan (work demand) dan pekerjaan yang berlebih (work overload) adalah sumber potensial yang memunculkan stressor dari peran. Beberapa studi menjelaskan bahwa stressor tersebut memiliki hubungan dengan kepuasan hidup (Prottas 2008). Namun, sebagian menyatakan tidak berhubungan (Fritz et al. 2010). Tuntutan pekerjaan yang berlebihan memiliki pengaruh negatif yang tidak langsung yang dimediasi oleh konflik keluarga-pekerjaan 
(Lilly, University, and Virick 2007). Namun, tuntutan pekerjaan yang tinggi akan memiliki pengaruh positif yang langsung pada kepuasan hidup, dengan argumentasi keamanan kerja (job security) dan perasaan dibutuhkan oleh organisasi.

\section{Diskusi dan Pembahasan}

Kepuasan kehidupan pekerja menjadi sangat menarik untuk menjadi bahan perhatian, terlebih pada pekerja perempuan. Kesimpulan Akhter (2015) menunjukkan gender mempengaruhi kesejahteraan subjektif dimana perempuan dan laki laki memiliki perbedaan kesejahteraan psikologis. Inglehart (2002) juga menyebutkan bahwa kesejahteraan subjektif muncul atas interaksi gender dimana kelompok perempuan lebih muda merasakan kebahagiaan yang lebih tinggi dibandingkan kelompok laki-laki dan perempuan yang berusia lebih tua. Higgins \& Duxbury (1992) menyimpulkan bahwa wanita yang tidak puas pada area kerja dan kehidupan adalah mereka yang tidak berorientasi pada pekerjaan, sehingga memilih keluar dari angkatan kerja dibandingkan tetap berada pada pasar kerja. Penemuan ini dapat menjelaskan bahwa terdapat kesenjangan gender pada korelasi antara pekerjaan dan kepuasan hidup. Namun, argumen ini mengabaikan ketergantungan finansial banyak perempuan pada pekerjaan mereka. Beberapa artikel menyebutkan alasan atas tercapainya kepuasan hidup atas pekerja perempuan didorong oleh faktor pemenuhan kebutuhan hidup, pekerjaan sebagai sarana untuk berkembang dan tekanan atas pekerjaan.

\section{Kepuasan Hidup dan Pemenuhan Kebutuhan pada Pekerja Perempuan}

Perubahan nilai-nilai sosial berubah seiring dengan terlibatnya perempuan sebagai pekerja sebagai pencari nafkah keluarga. Korelasi kepuasan hidup dan pekerjaan lebih kuat pada perempuan daripada laki laki (Babin \& Boles, 1998). Perempuan lebih merasakan kepuasan atas pekerjaannya ketika mereka memiliki kontribusi yang signifikan pada total pendapatan di rumah tangga. Melalui penelitian tersebut diatas terdapat argumen mengenai pemenuhan kebutuhan atas finansial pada pekerja perempuan adalah pendorong kepuasan hidup.

Gagasan selanjutnya mengenai pekerjaan sebagai pemenuhan kebutuhan atas power dan status dijelaskan oleh studi Raven (1959) bahwa kemampuan perempuan untuk mempengaruhi (power) berasal dari keterampilannya membina hubungan dengan orang lain, yang disebut referent power. Pekerja perempuan lebih diasosiasikan dengan perilaku yang hangat, ekspresif, menyenangkan dan mudah bersosialisasi (Mladinic 1989). Pekerja perempuan juga memiliki tingkat agreeableness yang lebih tinggi dibandingkan laki laki (Li, Murata, and Shu Li 2010). Dalam menjalani peran kepemimpinan, perempuan lebih mengedepankan gaya yang demokratis (Carli 2002). Terdapat perbedaan antara perempuan dan laki-laki dimana perempuan memiliki kekuatan mempengaruhi melalui keterampilan interpersonal. Temuan ini juga memperkuat faktor pendorong kepuasan hidup atas pemenuhan kebutuhan interpersonal pada pekerja perempuan. Pekerja Perempuan menerima dorongan dan dukungan moral yang berasal dari teman kerja dalam menjalankan peran gandanya. Pekerja perempuan cenderung menempatkan kolaborasi, dibanding kompetisi dalam membangun jaringan bersama koleganya (Smith and Fisher 2020). 


\section{Kepuasan hidup dan Aktivitas Berkembang pada Pekerja Perempuan}

Aspek tantangan, pertumbuhan dan kebermaknaan menjadi sumber kepuasan hidup pada dimensi aktivitas bekerkembang. Aspek pertama, yaitu tantangan adalah bagian dari proses pengemban kapabilitas pekerja perempuan, melalui tanggung jawab dan kompleksitas pekerjaan yang dihadapinya. Bertahannya perempuan dalam bekerja dibentuk atas dasar komitmen dalam menjalankan peran beragam yang berpotensi tidak akan pernah seimbang antara pekerjaan dan kehidupan (Smith and Fisher 2020). Burke et al. (1999) menyimpulkan bahwa terdapat korelasi positif antara tantangan pekerjaan dan kepuasan hidup pada sampel kelompok professional perempuan di Filipina. Aryee (1992) menyimpulkan bahwa tidak terdapat hubungan antara kompleksitas pekerjaan, variasi pekerjaan dan kepuasan hidup. Komitmen pekerja perempuan atas tantangan pekerjaan dan tanggung jawab di rumah tangga menjadi pemicu buruknya kondisi work life balance dan well being (Smith and Fisher 2020). Pekerja perempuan yang memiliki motivasi dan determinasi untuk berhasil dalam tantangan pekerjaan dan rumah tangganya, dapat menciptakan work life balance dan berkompromi dengan personal well being. Sehingga motivasi dan kepuasan intrinsic diperlukan untuk dapat mencapai kepuasan hidup pekerja perempuan.

Kedua, aspek pertumbuhan mendorong pekerja perempuan untuk tetap belajar dan menambah pengetahuan. Studi Smith \& Fisher (2020) menyimpulkan bahwa sekelompok pekerja perempuan yang telah berkeluarga memutuskan untuk melanjutkan pendidikan ke perguruan tinggi dan mampu memberikan pemberdayaan atas kehidupannya. Studi Ford \& Parker (2008) menyebutkan bahwa pekerja perempuan menyadari kehadiran bias gender dalam proses evaluasi pekerjaan, sehingga mereka menetapkan standar yang lebih tinggi daripada laki laki. Terdapat hubungan yang signifikan antara inisiatif pengembangan diri pekerja perempuan terhadap resiliensi dibandingkan pekerja laki-laki (Thapa 2018). Upaya pekerja perempuan melalui motivasi dan pengembangan individu adalah bentuk dari resiliensi dalam menjalani peran gandanya.

Ketiga, aspek kebermaknaan pekerjaan. Makna dari pekerjaan memberikan implikasi positif bagi individu dan organisasi, seperti: employee well being, kepuasan kerja dan retensi pada pekerjaannya. Terdapat perbedaan dimensi kebermaknaan pekerjaan dari pekerja perempuan pada kelas sosial yang beragam di Inggris. Perbedaan ini dipengaruhi oleh persepsi, Implikasi pekerja persepsi pada pilihan karir dan pengalaman bekerja (Hutmire 2016). Terdapat tekanan atas kelompok pekerja perempuan dari kelas sosial yang lebih tinggi di Inggris dalam hal pemilihan karir yang cocok dengan kelas sosialnya, sebaliknya pada pekerja perempuan dari kelas sosial yang lebih rendah. Berdasarkan perspektif keadilan sosial, persepsi mengenai kebermaknaan pekerja dapat membantu organisasi untuk menghilangkan hambatan yang dialami kelompok pekerja perempuan yang termarjinalkan (Dik and Duffy 2009). Dari beberapa studi mengindikasikan bahwa pekerja perempuan cenderung untuk mengalami stress terhadap lingkungan kerjanya (Fransson et al. 2012) dimana mereka perlu mencari cara untuk mereduksi tingkat stress yang dialaminya melalui persepsi makna pekerjaan yang positif bagi kehidupan mereka Vincent-Höper et al. (2012). Pengelolaan stress yang baik memberikan ketercapaian tingkat kepuasan hidup yang lebih baik. 


\section{Kepuasan Hidup dan Tekanan Pekerjaan pada Pekerja Perempuan}

Faktor kepuasan hidup yang bersumber dari tekanan pekerjaan dikelompokan menjadi aspek konflik pekerjaan dan selain pekerjaan, tekanan pekerjaan dan tekanan peranan. Navarro \& Salverda (2019) mengkonfirmasi bahwa kelompok perempuan dan laki laki memiliki perbedaan nilai dan perspektif dalam domain pekerjaan dan keluarga. Aspek pertama yaitu konflik pekerjaan dan selain pekerjaan pada pekerja perempuan dapat tercermin pada konflik pekerjaan dan kehidupan. Hubungan work life balance dan well being dari pekerja perempuan bernilai negatif jauh lebih tinggi dibandingkan pekerja laki laki dikarenakan peningkatan beban kerja, seiring berjalan dengan penambahan beban kerja domestik (Christensen et al. 2013). Kossek et al. (1998) membuat meta analisis yang mendemonstrasikan bahwa terdapat korelasi negatif antara kepuasan hidup dan konflik keluarga dan pekerjaan pada perempuan. Kerepotan sederhana yang terjadi di tengah aktivitas harian berhubungan dengan kepuasan hidup (Erlandsson et al. 2010). Pekerja perempuan lebih mungkin berkompromi dengan personal well being untuk mengutamakan kepentingan keluarganya

Aspek kedua adalah stressor dari pekerjaan yang dialami oleh pekerja perempuan. Motivasi pekerja perempuan dapat terbangun pada lingkungan yang bebas tekanan. Kombinasi stress atas tuntutan pekerjaan dan well being dapat menurunkan well being yang bersifat objektif, ditunjukan oleh respon negatif fisik dan emosi (Deeming 2013). Lebih khusus pekerja perempuan menghadapi situasi kerja yang sumber pendorong stress dalam lingkungan kerja. Buruknya kebijakan maternitas perusahaan (Akhtar and Khan 2020), perundungan secara verbal dan fisik serta pelecehan seksual (Tinkler and Zhao 2019), kelebihan jam kerja memberikan tekanan baik secara fisik dan mental (Ravenswood et al. 2018), sehingga menjadi penyebab turunya kepuasan kerja serta intensi untuk berpindah pekerjaan.

Adaptasi sosial pekerja perempuan mempengaruhi well being dengan membatasi kesempatan, mengurangi pendapatan dan ekspektasi (Deeming 2013). Sousa \& Lyubomirsky (2001) menyebutkan sebuah paradox ketika terdapat kondisi kerja yang buruk, pekerja perempuan masih merasakan kepuasan kerja. Clark (1997) berargumen bahwa tingkat kepuasan perempuan cenderung lebih mudah dipenuhi karena harapan yang tidak terlalu tinggi.

Aspek ketiga adalah tekanan dari peran (role stressor). Permintaan kerja (work demand) dan peran yang berlebih (role overload) adalah sumber tekanan atas peran pekerja perempuan. Teori ekspansi memandang bahwa peranan yang bervariasi dalam pekerjaan dapat meredam tingkat stress karena dapat memperkuat nilai diri dalam organisasi (Nordenmark 2004). Melalui kemampuan tersebut, well being dari pekerja perempuan dapat ditingkatkan yang seiring berjalan dengan peningkatan kepercayaan diri, pengetahuan dan keterampilan yang lebih baik (Mcgregor 2010). Namun demikian, Huang et al. (2020) menjelaskan bahwa penambahan jam kerja akan gangguan kesehatan, yang dalam jangka waktu panjang, sehingga merusak konflik pekerjaan dan keluarga serta kepuasan hidup. 


\section{Kesimpulan}

Dari hasil kajian mengenai kepuasan hidup, terdapat peluang bagi para peneliti untuk mengeksplorasi lebih jauh mengenai kepuasan hidup, dengan domain pekerjaan dari para pekerja pekerja perempuan secara personal. Kondisi kelompok pekerja perempuan yang rentan dan memiliki posisi tawar yang rendah di tempat kerja, meningkatkan dugaan terdapat pengaruh domain pekerjaan pada kepuasan hidupnya. Pendekatan kepuasan hidup secara bottom-up menjadi teori yang melandasi domain pekerjaan sebagai sumber pendorong kepuasan hidup. Artikel ini menyebutkan beberapa faktor dari domain pekerjaan yang relevan menjadi determinan kepiasan hidup bagi pekerja perempuan. Faktor pendorong tersebut meliputi: kepuasan atas kebutuhan (need satisfaction), keinginan untuk berkembang (growth) dan tekanan dari pekerjaan (work stressor). Dorongan untuk mencapai kepuasan atas kebutuhan terdiri kebutuhan akan finansial, interpersonal, kekuasaan dan status, Sementara kepuasan untuk berkembang didasari oleh dorongan pekerja perempuan untuk menghadapi tantangan, mencapai pertumbuhan dan kebermaknaan. Faktor tekanan pekerjaan juga membentuk kepuasan hidup pekerja perempuan yang meliputi: konflik pekerjaan dan kehidupan, tekanan dari pekerjaan dan peranan yang dijalankan pekerja perempuan.

\section{Daftar Referensi}

Akhtar, Tazeem, and Muhammad Athar Khan. 2020. "Pregnancy and Maternity at Workplace, a Qualitative Study to Know the Employers' Perspective.”Journal of Evolution Medical and Dentistry Science 9(09). https://jemds.com/data_pdf/nawab sher 3-MAR2.pdf.

Akhter, Sana. 2015. "Psychological Well-Being in Student of Gender Difference." The International Journal of Indian Psychology 2(4).

Aryee, Samuel. 1992. "AntecE, Dents and Outcomes of Work-Family Conflict Among MarriE, d Professional Women: Evidence from Singapore." Human Relations 45(8): 813-37.

Burke, Ronald J., Mustafa Koyuncu, Lisa Fiksenbaum, and Halil Demirer. 2009. “Time Affluence, Material Affluence and Well-Being among Turkish Managers." Cross Cultural Management 16(4): 386-97.

Burke, Ronald J, Louie A. Dmnagkacia, Ermias Mamo, and . 1999. "Predictors of Life Satisfaction Among Filipino Managerial And Professional Women '.” Psychological Reporis 84: 805-8.

Carli, Linda. 2002. “Gender, Interpersonal Power, and Social Influence.” Journal of Social Issues 55(1, 1999). Christensen, Kathleen, Kathleen Christensen, Alfred P Sloan Foundation, and New York. 2013. "Launching the Workplace Flexibility Movement : Work Family Research and a Program of Social Change a Program of Social Change." Community, Work and Family 8803: 261-284. https://doi.org/10.1080/13668803.2013.820092.

De Cuyper, Nele, and Hans De Witte. 2006. "The Impact of Job Insecurity and Contract Type on Attitudes, Well-Being and Behavioural Reports: A Psychological Contract Perspective.” Journal of Occupational and Organizational Psychology 79(3): 395-409.

D.C.Shin;D.M. Johnson. 1978. “Avowed Happiness as an Overall Assessment of the Quality of Life Author ( s ): D . C . Shin and D . M . Johnson Published by: Springer Content in a Trusted Digital Archive . We 
Use Information Technology and Tools to Increase Productivity and Facilitate.” 5(4): 475-92.

Davis, Murray S., and Mihaly Csikszentmihalyi. 1977. "Beyond Boredom and Anxiety: The Experience of Play in Work and Games." Contemporary Sociology 6(2): 197.

Day, Aria L., and Steve Jreige. 2002. "Examining Type A Behavior Pattern to Explain the Relationship between Job Stressors and Psychosocial Outcomes.” Journal of Occupational Health Psychology 7(2): 109-20.

Deeming, Christopher. 2013. “Addressing the Social Determinants of Subjective Wellbeing: The Latest Challenge for Social Policy.” Journal of Social Policy: 541-65.

Deneve, Kristina M, and Harris Copper. 1998. "The Happy Personality DeNeve_OPTIONAL.Pdf." Psychological Bulletin 124(2): 197-229. https://www.gwern.net/docs/iq/1998-deneve.pdf.

Diener, Ed. 1984. “Subjective Well-Being.” Psychological Bulletin 95(3): 542-75.

Dik, Bryan J, and Ryan D Duffy. 2009. "Calling and Vocation at Work.” In The Counselling Psychologis, , 424-50.

Ed, Diener. Robert A, Emmons. Randy J, Larsen. Sharon Griffin. 1985. "The Satisfaction with Life Scale."

Erlandsson, Lena-Karin, Cecilia Björkelund Lena-Karin Erlandsson, Lauren Lissner, and Carita Håkansson. 2010. "Women's Perceived Frequency of Disturbing Interruptions and Its Relationship to Self-Rated Health and Satisfaction with Life as a Whole." Journal of the International Society for the Investigation of Stress 25: 225-32. https://onlinelibrary.wiley.com/doi/abs/10.1002/smi.1287.

Ervasti, Heikki, and Takis Venetoklis. 2010. "Unemployment and Subjective Well-Being: An Empirical Test of Deprivation Theory, Incentive Paradigm and Financial Strain Approach.” Acta Sociologica 53(2): 119-39.

Ford, Michele, and Lyn Parker. 2008. "Introduction: Thinking about Indonesian Women and Work." In $M$. Ford \& L. Parker [Eds], London and New York: : Routledge, 1-16.

Fransson, Eleonor I. et al. 2012. "Comparison of Alternative Versions of the Job Demand-Control Scales in 17 European Cohort Studies: The IPD-Work Consortium.” BMC Public Health 12(1): 1-10.

Fritz, Charlotte, Maya Yankelevich, Anna Zarubin, and Patricia Barger. 2010. "Happy, Healthy, and Productive: The Role of Detachment from Work during Nonwork Time." Journal of Applied Psychology 95(5): 977-83.

FUSILIER, MARCELLINE R., DANIEL C. GANSTER, and BRONSTON T. MAYES. 1986. "The Social Support and Health Relationship: Is There a Gender Difference?” Journal of Occupational Psychology 59(2): 145-53.

Gadermann, Anne M., and Bruno D. Zumbo. 2007. "Investigating the Intra-Individual Variability and Trajectories of Subjective Well-Being.” Social Indicators Research 81(1): 1-33.

Hanlon, Edward Merrill. 2013. "Male Reproductive Strategies And Mating Displays In The Ocellated Turkey ( Meleagris Ocellata)." University of Mississippi Follow. https://egrove.olemiss.edu/cgi/viewcontent.cgi?article=1375\&context=etd.

Higgins, Christopher A ., and Linda E . Duxbury. 1992. "Work-Family Conflict: A Comparison of DualCareer and Traditional-Career Men.” Journal of Organizational Behavior 13(4): 389-411. 
Huang, Shu-ling, Ren-hau Li, Shu-yi Fang, and Feng-cheng Tang. 2020. "Work Hours and Difficulty in Leaving Work on Time in Relation to Work-to-Family Conflict and Burnout Among Female Workers in Taiwan." Journal od Enviromental Research and Public Health 17(6).

Hutmire, Jennifer. 2016. "Meaningfulness of Work as Perceived by Women from Diverse Social Classes:" Walden University. https://scholarworks. waldenu.edu/cgi/viewcontent.cgi?article=3101\&context=dissertations.

Inglehart, Ronald. 2002. “Gender, Aging, and Subjective Well-Being.” International Journal of Bank Marketing comparative sociology 43(3-5): 391-408.

Jørgen Goul Andersen. 2002. "Coping with Long-Term Unemployment : Economic Security , Labour Market Integration and Well-Being." International Journal of Social Welfare 11: 178-90.

Judge, Timothy A., Edwin A. Locke, Cathy C. Durham, and Avraham N. Kluger. 1998. "Dispositional Effects on Job and Life Satisfaction: The Role of Core Evaluations." Journal of Applied Psychology 83(1): 1734.

Klaveren, Maarten Van, Kea Tijdens, Melanie Hughie-williams, and Nuria Ramos Martin. 2010. An Overview of Women's Work and Employment in Indonesia Decisions for Life MDG3 Project. Amsterdam. https://www.ituc-csi.org/IMG/pdf/Country_Report_No14-Indonesia.pdf.

Kossek, Ellen Ernst, Cynthia Ozeki, and Dominguez Hills. 1998. "Work-Family Conflict, Policies , and The Job-Life Satisfaction Relationship: A Review and Directions for Organizational Behavior-Human Resources.” (May 2014).

Levesque, Roger J. R. 2011. Encyclopedia of Adolescence. Springer Sex Roles and Gender Roles. New York. https://link.springer.com/referenceworkentry/10.1007\%2F978-1-4419-1695-2_602.

Li, Yan-mei, Koji Murata, and Shu Li. 2010. "Better Safe than Sorry : Situational Correction in Interpersonal Competition." (August).

Lilly, Juliana, Wendy J Casper University, and Meghna Virick. 2007. "Doing More with Less An Analysis of Work Life Balance among Layoff.” Career Development International (June 2014).

Llewellyn E. vanZyl, Elmari Deacon, Sebastiaan Roothman. 2010. "And Work Engagement of Industrial / Organisational Psychologists.” 36(1): 1-11.

Luhmann, Maike, and Michael Eid. 2009. "Does It Really Feel the Same? Changes in Life Satisfaction Following Repeated Life Events." Journal of Personality and Social Psychology 97(2): 363-81.

Mcgregor, J Allister. 2010. "The Capability Approach and the Politics of a Social Conception of Wellbeing." European Journal of Social Theory 13(4): 501-19. https://doi/pdf/10.1177/1368431010382762.

Mladinic, Antonio. 1989. "Gender Stereotypes and Attitudes Toward Women and Men." Personality and Social Psychology Bulletin 15(December).

Myers, David G., and Ed Diener. 1995. “Who Is Happy?” Psychological Science 6(1): 10-19.

Navarro, María, and Wiemer Salverda. 2019. "Earner Position and Job and Life Satisfaction : Do Contributions to the Household Income Have the Same Effect by Gender and Occupations ?" Journal of Happiness Studies 20(7): 2227-50. https://doi.org/10.1007/s10902-018-0045-5.

Nordenmark, Mikael. 2004. "Multiple Social Roles and Well-Being : A Longitudinal Test of the Role Stress 
Theory and the Role Expansion Theory REFERENCES Linked References Are Available on JSTOR for This Article : You May Need to Log in to JSTOR to Ac.” Acta Sociologica 47(2): 115-26.

Oishi, Shigehiro, Ed Diener, Eunkook Suh, and Richard E. Lucas. 1999. "Value as a Moderator in Subjective Well-Being." Journal of Personality 67(1): 157-84.

Prottas, David. 2008. "Do the Self-Employed Value Autonomy More than Employees?: Research across Four Samples." Career Development International 13(1): 33-45.

Rau, Renate. 2006. "Learning Opportunities at Work as Predictor for Recovery and Health." European Journal of Work and Organizational Psychology 15(2): 158-80.

Raven, Bertram H. 1959. The Bases of Social Power. ed. Ann Arbor. California: MI: Institute for Social Research.

Ravenswood, Katherine et al. 2018. "Physical and Verbal Abuse, Work Demands, Training and Job Satisfaction amongst Aged-Care Employees in the Home and Community Sector Community Sector." Labour \& Industry: a journal of the social and economic relations of work 27(4): 302-18. https://doi.org/10.1080/10301763.2018.1427846.

Simon, Lauren S., Timothy A. Judge, and Marie D.K. Halvorsen-Ganepola. 2010. "In Good Company? A Multi-Study, Multi-Level Investigation of the Effects of Coworker Relationships on Employee WellBeing.” Journal of Vocational Behavior 76(3): 534-46. http://dx.doi.org/10.1016/j.jvb.2010.01.006.

Smith, Joanne, and Jenny Fisher. 2020. "Adding University to Work and Life: The Work - Life Balance and Well-Being Experiences of Women Who Combine Employment , HE Learning and Care of the Family." Community, Work \& Family 0(0): 1-20. https://doi.org/10.1080/13668803.2020.1779662.

Sousa, Lorie, and Sonja Lyubomirsky. 2001. Encylopedia of Women and Gender: Sex Similarities and Differences and the Impact of Society on Gender. San Diego, CA: Academic Press.

Staines, Graham L, Kathleen J Pottick, and Deborah A Fudge. 2015. "Wives ' Employment and Husbands ' Attitudes Toward Work and Life Wives' Employment and Husbands' Attitudes Toward Work and Life." (February 1986).

Thapa, Asmita. 2018. "Resilience, Personal Growth Initiative and Employees Productivity at Workplace Introduction-." In First Pan IIT International Management Conference,

Tinkler, Justine E, and Jun Zhao. 2019. "The Sexual Harassment of Federal Employees : Gender , Leadership Status , and Organizational Tolerance for Abuses of Power." Journal of Public Administration Research and Theory 30(3): 349-64. https://remote-lib.ui.ac.id:2184/jpart/article/30/3/349/5618607.

Todd, Samuel Y., Kenneth J. Harris, Ranida B. Harris, and Anthony R. Wheeler. 2009. "Career Success Implications of Political Skill.” Journal of Social Psychology 149(3): 279-304.

Wanous, John P, Arnon E Reichers, and Michael J Hudy. 1997. “Overall Job Satisfaction: How Good Are Single-Item Measures?" Journal of Applied Psychology 82(2): 247-52. https://pubmed.ncbi.nlm.nih.gov/9109282/.

Wilensky, Harold L. 1960. "Work, Careers and Social Integration.” International Social Science Journal 12(4): 543-60. https://psycnet.apa.org/record/1962-00867-001.

Winefield, Anthony H. et al. 1991. “A Longitudinal Study of the Psychological Effects of Unemployment and 
Unsatisfactory Employment on Young Adult.” Journal of Applied Psychology 178(4): 246-51.

Wu, Chia Huei. 2009. "Enhancing Quality of Life by Shifting Importance Perception among Life Domains." Journal of Happiness Studies 10(1): 37-47. 